\title{
Estimating Residential Electricity Demand Responses in Pakistan's Punjab
}

\section{Theresa Chaudhry*}

\begin{abstract}
In this paper, we aim to understand residential electricity demand responses to changes in income, in order to assist policymakers in managing demand for electricity and evaluating tariff increases associated with proposed projects for increasing supply, while minimizing the impact on poverty.
\end{abstract}

Keywords: Electricity, demand, residential, Pakistan.

JEL Classification: Q41, D12, E39.

\section{Introduction}

Given the large electricity shortages that Pakistan has been facing over the last several years, policymakers are struggling to reconcile the large gaps between electricity supply and demand. The possible responses to shortages include (i) increasing electricity generating capacity, thus reducing supply constraints, and (ii) managing demand through tariff increases. In some instances, policies may be directed at both the supply and demand sides simultaneously.

As can be seen in Appendix Table-1, estimates by the Private Power and Infrastructure Board (PPIB) place heavy emphasis on independent power producers (IPPs) to eliminate electricity shortages, with the estimated supply from IPPs to nearly double between March 2009 and mid-2012. Recent evaluations of proposed electricity generating schemes through rental power plants projected such steep increases in electricity tariffs (up to 45\%) that the Asian Development Bank (ADB) refused to endorse them. ${ }^{1}$ Given that nearly half of electricity is consumed by residential users, understanding the demand

\footnotetext{
* Associate Professor, Department of Economics, Lahore School of Economics.

1 "Rental plants to cause steep rise in power tariff: ADB," 18 January 2010, www.dawn.com.
} 
response of households to tariff changes is critical. ${ }^{2}$ On one hand, tariff increases may be useful in managing demand. On the other hand, raising prices further may exacerbate poverty among a population that has already dealt with high food-price inflation in recent years. ${ }^{3}$ Optimally, tariffs may be adjusted in such a way as to manage demand (and hopefully even stimulate energy efficiency) while minimizing the impact on poverty. The first step toward this is to understand the demand responses of energy consumers to hypothetical price changes. As we can see in Table-1, electricity is the utility to which the greatest proportion of consumers is connected.

\section{Table-1: Utility Connections in Punjab}

\begin{tabular}{lcc}
\hline Utility & $\begin{array}{c}\text { Households with a } \\
\text { Connection } \\
\text { 2003/04 (\%) }\end{array}$ & $\begin{array}{c}\text { Households with a } \\
\text { Connection } \\
\text { 2007/08 (\%) }\end{array}$ \\
\hline Electricity & 85.3 & 92.5 \\
Gas & 24.8 & 26.4 \\
Water & 28.0 & - \\
\hline
\end{tabular}

Source: Author's calculations based on data from the Multiple Indicators Cluster Survey (MICS) for 2003/04 and the MICS 2007/08 Provincial Report.

Studies of energy demand fall into two major categories: (i) time series analyses of aggregated (either economy- or sector-wide) data, and (ii) micro-level data studies of the price-elasticity of demand. We will not concentrate on the macro-level time series analyses here, since the focus of this paper is on micro-level analysis.

Early studies of residential electricity demand relied on log-linear functional forms, which provide a convenient framework for the calculation of elasticities. Innovations to this approach included the substitution of the marginal electricity price (in place of average price) given the increasing rates per block, accounting for the endogeneity of appliance ownership, and differentiating between peak and off-peak usage (Madlener, 1996). Transcendental logarithmic functional forms (translog) were introduced in order to get away from some of the restrictive functional forms (e.g., CobbDouglas and constant elasticity of substitution) utilized in the log-linear

2 According to the 2007/08 Pakistan Economic Survey, 45.6\% of electricity was consumed by households in 2007/08 (Table-15.7, pg. 250). This is up from 33\% in 1990/91, partially because industrial and agricultural users switched to natural gas as a result of steep increases in electricity tariffs (Siddiqui, 2004).

${ }^{3}$ See Chaudhry and Chaudhry (2008). 
estimations. While the translog specifications allowed more flexibility and for the calculation of substitution elasticities between different fuels, they suffered their own drawbacks, including large numbers of parameters to estimate, robustness problems, restriction to short-run elasticities, and inability to include the stock of energy using devices (Madlener, 1996). Models of qualitative choice put the decisions about energy-consuming equipment on the front burner through a two-stage estimation procedure where, in the first stage the decision to buy equipment is modeled, and in the second stage, energy demand is estimated (Madlener, 1996). Another common framework for analyzing household level energy data is based on household production theory, which implies that households get utility not from the energy as such, but rather from the services derived from it (in conjunction with appliances, household labor, and other inputs) (Madlener, 1996).

\section{Literature on Pakistan}

There are a number of time-series analyses of energy in Pakistan using aggregate data. Khan and Ahmed (2009) estimate total demand equations for three energy sources, electricity, natural gas, and coal, based on real income and the price level, using aggregate data for the period 1972-2007. Their results show electricity to be relatively less price and income elastic. Tariq et al. (2009) studied an aggregate model of residential energy demand over the period 1979-2006, finding electricity demand to be price inelastic and income elastic in both the short and long run. Siddiqui (1999) found the own price elasticity for electricity again to be low (at around 0.5 ) in her examination of sector level demands for electricity, natural gas, and petroleum products for the period 1971-1997, and that the largest impacts on electricity demand were due to increasing the number of consumers.

An earlier paper (Burney and Akhtar, 1990) computes price and income elasticities for firewood, kerosene, natural gas, electricity, and "other fuels" (mainly biomass) using household level data from the 1984/85 Household Income and Expenditure Survey (HIES). Using the extended linear expenditure system, they estimate price, cross price, income, and expenditure elasticities for the five fuel categories, separately for both urban and rural areas. The estimated price elasticities are extremely low, which the author interprets as only the households' minimum fuel requirements being met, while the income elasticities (still less than unity) were significantly higher. 


\section{Special Econometric Issues}

Residential demand comes out of a utility maximization problem, often based on household production models. In studying residential electricity demand, a number of thorny econometric issues arise. Among these are the endogeneity of appliance ownership, heterogeneous consumers, seasonality of appliance utilization, bounded rationality of consumers, and simultaneity of marginal price and consumption.

Appliance ownership and housing characteristics are endogeneous to energy demands. On one hand, energy use is positively related to the number of appliances owned and the size of the dwelling; however the appliance stock is not exogenous to the model because the appliance stock also depends on energy prices in the long run. The seasonality of appliance utilization can be accounted for via separate regression equations for different seasons (Filippini and Pachauri, 2002) or by including weather information such as heating and cooling degree days (HDD and CDD), as in Reiss and White (2005). ${ }^{4}$ Households may be heterogeneous in their responses to price changes, which may be reflected in the "portfolio" of appliance ownership.

The last two problems, bounded rationality and simultaneity of marginal price and consumption, are related to the nonlinearity of electricity pricing, which tends to be based on the principle of increasing marginal prices per block of usage. Bounded rationality refers to the nonoptimizing behavior of consumers due to the complex, nonlinear pricing of electricity which leads consumers to be uncertain of the marginal cost of electricity they face. In response, consumers may be basing their decisions on the average cost of electricity or using a "rule of thumb" decision rule (Borenstein, 2009). While the earliest micro-level studies used the average price of electricity, it was quickly realized that the marginal price (rather than the average) was the relevant variable (Madlener, 1996). However, more recent studies suggest consumers may actually be responding to average prices (Borenstein, 2009; and Ito, 2010).

The simultaneity problem of marginal price and consumption is derived from the nonlinear, convex budget constraint that households face in utility maximization. Since electricity is priced through an increasing block tariff, as the number of units consumed increases the marginal price rises, giving rise to a nonlinear budget constraint as in Figure-1. The simultaneity

${ }^{4}$ Filippini and Pachauri (2002) recognize the seasonality of electricity use in India by estimating separate price elasticities for winter, summer, and monsoon, finding the least elasticity in the summer months. 
between the marginal price of electricity and demand can best be explained by Figure-1 and the accompanying explanation, based on Maddock et al. (1992). This approach was derived from work originally done by Hausman (1979) on labor supply models. Other seminal contributions in the literature on nonlinear budget constraints include Hausman (1985) and Moffitt (1990).

\section{Figure-1: The Household's Nonlinear Budget Constraint with Increasing Block Tariffs}

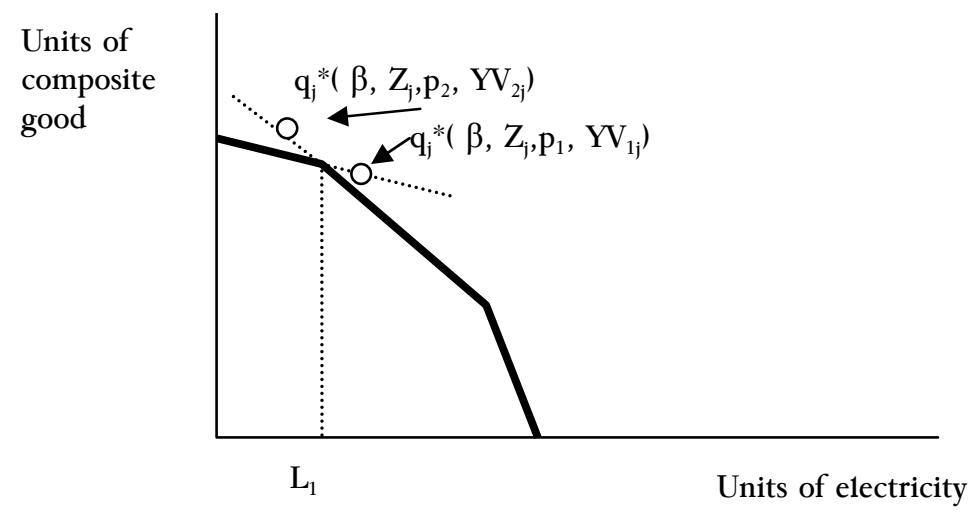

Consider the case of only three different tiers, with prices $\mathrm{p}_{1}, \mathrm{p}_{2}$, and $\mathrm{p}_{3} . \mathrm{L}_{1}$ is the amount of electricity at which the unit price of electricity increases from $\mathrm{p}_{1}$ to $\mathrm{p}_{2}$. For the $j$ th household, $\mathrm{q}_{\mathrm{j}}{ }^{*}$ represents the desired level of consumption, $\beta$ are parameters of the demand functions, $Z_{j}$ are household characteristics, $\mathrm{p}_{\mathrm{i}}$ is the price of a particular block of electricity $i$, and $\mathrm{YV}_{\mathrm{ij}}$ is the virtual income for household $j$ at price tier $i$. The household's actual budget constraint is the nonlinear budget in bold, but the virtual income refers to the fact that if a household consumes in the second block of electricity (greater than $\mathrm{L}_{1}$ ), then the linearized budget constraint would look as if income were higher than it actually is (on the graph, extending the dotted line from $\mathrm{L}_{1}$ to the vertical axis) since the first units of electricity were cheaper than the later ones. If the household maximizes its utility, then it will choose the feasible consumption point that is closest to the optimal position. If a household's desired electricity $\mathrm{q}_{\mathrm{j}}^{*}\left(\beta, \mathrm{Z}_{\mathrm{i}}, \mathrm{p}_{\mathrm{ij}}, \mathrm{YV}_{\mathrm{ij}}\right)$ is not near one of the "kink points", then the solution is straightforward and the household consumes $\mathrm{q}_{\mathrm{j}}{ }^{*}$, the desired level. On the other hand, for desired electricity near $\mathrm{L}_{1}$, the household's decision rule becomes more complex. In Figure-1, the desired electricity at the first tier of pricing, $q_{j}^{*}\left(\beta, Z_{j}, p_{1 j}, Y_{1 j}\right)$, is greater than $\mathrm{L}_{1}$. But if the household moves up into the second price tier, $\mathrm{p}_{2}$, the desired electricity $\mathrm{q}_{\mathrm{j}}^{*}\left(\beta, \mathrm{Z}_{\mathrm{j}}, \mathrm{p}_{2 \mathrm{j}}, \mathrm{YV}_{2 \mathrm{j}}\right)$ is less than $\mathrm{L}_{1}$; hence the household chooses to consume exactly $\mathrm{L}_{1}$ units. 
Earlier attempts to deal with this problem include instrumental variables (IV) analysis and Heckman-style two-step selection models. As is often the case, IV analyses are attacked on the grounds of the quality of the instrument. The Heckman type models follow a two-step procedure, by first using exogenous determinants of the likelihood of being on a certain part of the budget constraint and then using this constructed probability as a variable to correct for the sample selection. These procedures can help to eliminate endogeneity, but do not model the choice of many consumers to locate at one of the kink points of the budget constraint.

Reiss and White (2005) use the generalized method of moments (GMM) to disentangle effects of nonlinear pricing, heterogeneous consumers (in their appliance ownership), and consumption aggregation over time. In their mode1, consumers sort themselves into the different tiers of a nonlinear price schedule, in the spirit of the self-selection models explored by Heckman (1979). Their approach has the additional benefit of allowing the researcher to estimate the effects of changing the tariff.

Another recent stream of research dealing with nonlinear pricing entails discrete-continuous choice (DCC) modeling, even though the procedure has been around for some time (Hanemann, 1984). This technique has many applications, but with respect to nonlinear pricing environments, it has been applied to electricity (Maddock, Castano, and Vella, 1992; McRae, 2009), water and sanitation (Olmstead, 2009), cell phone plans (Iyengar, 2006), and labor supply subject to varying income tax rates (Ransom, 1987). It entails the specification of a multipart maximum likelihood function which estimates the probabilities of a consumer choosing a straight segment of the budget constraint or a "kink" point.

\section{Data}

The data used in this study is the Punjab Multiple Indicators Cluster Survey (MICS) for 2003/04, collected between September and December 2003 by the Punjab Bureau of Statistics. In addition to the required information on electricity expenditures, the MICS has information on appliance ownership, housing and household characteristics, and income and expenditure per capita for over 30,000 households.' Given that we had precise tariff information for Lahore only, we later narrowed the sample to the 3,131 households in Lahore for which there was electricity bill data.

\footnotetext{
${ }^{5}$ While a newer, larger sample of households were surveyed for the 2007/08 round of the MICS, it did not include the disaggregated expenditure data needed for this type of study.
} 
In Table-2, we can see the breakdown of appliance ownership among households in all of Punjab. The most commonly owned appliances are air coolers and fans, owned by over $80 \%$ of households. Appliance ownership in the other categories has increased dramatically from 2003/04 to 2007/08.

Table-2: Appliance Ownership in Punjab, 2003/04 and 2007/08

\begin{tabular}{lccc}
\hline Appliance & $\begin{array}{c}\text { Percent of } \\
\text { Households } \\
\text { Owning } \\
\mathbf{2 0 0 3 / 0 4}\end{array}$ & $\begin{array}{c}\text { Percent of } \\
\text { Households } \\
\text { Owning } \\
\text { 2007/08 }\end{array}$ & $\begin{array}{c}\text { Increase } \\
\text { (in } \\
\text { percentage } \\
\text { points) }\end{array}$ \\
\hline Air Cooler or Fan & 83.3 & 86.4 & 3.1 \\
Sewing or Knitting Machine & 52.7 & 72.7 & 20 \\
Television & 41.6 & 63.2 & 21.6 \\
Washing Machine or Dryer & 37.8 & 48.8 & 11 \\
Water Pump & 31.7 & 54.5 & 22.8 \\
Refrigerator or Freezer & 27.9 & 40.3 & 12.4 \\
Radio & 13.4 & 40.0 & 26.6 \\
Air Conditioner & 2.8 & 6.6 & 3.8 \\
Personal Computer & 2.7 & 8.5 & 5.8 \\
Cooking Range or Microwave & 2.5 & 6.0 & 3.5 \\
\hline
\end{tabular}

Source: Author's calculations, based on MICS 2003/04, and MICS 2007/08 Provincial Report.

The information collected in the MICS 2003/04 from households on their utility bills included electricity, gas, and water. ${ }^{6}$ Since households were asked for the amount of their average bill, there was clustering of reported bills at rounded amounts. The distance between the points at which the clustering took place increased as the bill amounts increased. ${ }^{7}$

The questionnaire asks the household for its average monthly expenditure on electricity. One question which arises, especially when a

${ }^{6}$ Out of 30,758 households surveyed, there was electricity bill information for 25,801 households. Since 4,508 households had no electricity connection, there were only 449 households $(1.7 \%)$ who had access to electricity but were missing electricity bill information.

${ }^{7}$ For bills of $<$ Rs 200 , the reported electricity bills cluster at Rs 10 increments, for bills of Rs200-500 at Rs50 increments, for bills of Rs200-500, at Rs50 increments, For bills of Rs500-1,500 at Rs100 increments, for bills of Rs1,500-5,000 at Rs500 increments, and for bills above Rs5,000 at Rs1,000 increments. 
survey asks for an "average value," is whether the reported figure is actually an average, or whether it is principally based on the household's most recent bill. A simple weighted regression of electricity bills on the month of the interview (and also controlling for appliance ownership, size of dwelling, number of household members, and expenditure per capita) showed that there is no statistically significant relationship between the reported electricity bill and the month in which the household was surveyed. We will therefore take the reported expenditure as the average monthly expenditure for the year $2003 .^{8}$

Among the households who reported electricity bill information, we have the following breakdown of electricity usage, with the ranges of electricity usage according to the tariff schedule (Tables-3a and $3 \mathrm{~b}$ ). As we can see, around $80 \%$ of households consumed in the second and third tariff tiers, corresponding roughly to bills of between Rs. 150-900 (for all Punjab) and Rs. $200-1,100$ for Lahore. 'Another $10-15 \%$ of households consume in approximately the fourth tier. Only a few percent of households consume in the lowest and highest tariff tiers.

\footnotetext{
${ }^{8}$ If we include an urban dummy variable, the month of interview becomes statistically significant, but the wrong sign. If the electricity bill reported is closer to the most recent figure (rather than the average figure), then the month of the interview should have a negative effect. The MICS was conducted from September to December, and therefore electricity bills should fall in later months, as electricity demand falls in the winter months.

${ }^{9}$ Based on the published electricity tariffs (Economic Survey, 2006-07), bills in the second and third tiers should range from Rs. 120 - Rs. 910. Based on the rates in a sample bill from Lahore, bills in the second and third tiers should range from Rs. 153 - Rs. 1111. This is because, for bill amounts around or between the break points from one tier to the next, there was uncertainty about which tier the household was consuming. For all-Punjab especially, the minimum and maximum bills for a given tier were derived from the published electricity tariffs which, according to the Economic Survey 2006-07, only "cover some portion of the tariffs schedule." Also, given that households were citing their average bill, some households may be consuming in different tiers in different months.
} 
Table-3a: Distribution of Electricity Bills for Punjab, MICS 2003

\begin{tabular}{lccll}
\hline Electricity Bill & Frequency & Percent & Cumulative Percent \\
\hline <=Rs. 80 & 477 & 1.85 & 1.85 & \\
Rs. $81-149$ & 1,194 & 5.57 & 7.42 & \\
Rs. $150-249$ & 4,564 & 17.69 & 25.11 & \\
Rs. 250-299 & 1,369 & 5.31 & 30.41 & \\
Rs. 300-900 & 14,758 & 57.20 & 87.61 & \\
Rs. 901-999 & 39 & 0.15 & 87.76 & 100 \\
Rs. 1,000-5,000 & 3,353 & 13.00 & 100.76 & $\mathbf{1 0 0}$ \\
>Rs. 5,000 & 47 & 0.18 & 0.18 & \\
\multicolumn{1}{r}{ Total } & $\mathbf{2 5 , 8 0 1}$ & $\mathbf{1 0 0}$ & $\mathbf{1 0 0}$ & \\
\hline
\end{tabular}

Source: Author's calculations, based on MICS 2003/04.

Table-3b: Distribution of Electricity Bills for Lahore, MICS 2003

\begin{tabular}{|c|c|c|c|}
\hline Electricity Bill & Frequency & Percent & Cumulative Percent \\
\hline$<=\operatorname{Rs} 100$ & 52 & 1.66 & 1.66 \\
\hline Rs 101-199 & 59 & 1.88 & 3.55 \\
\hline Rs $200-300$ & 473 & 15.11 & 18.65 \\
\hline Rs 301-349 & 5 & 0.16 & 18.81 \\
\hline Rs $350-1,100$ & 2,046 & 65.35 & 84.16 \\
\hline Rs $1,101-1,200$ & 102 & 3.26 & 87.42 \\
\hline Rs 1,201 - 5,999 & 369 & 11.79 & 99.20 \\
\hline$>$ Rs6,000 & 16 & 0.51 & 100 \\
\hline Total & 3,122 & 100 & 100 \\
\hline
\end{tabular}

Source: Author's calculations, based on MICS 2003/04.

For purposes of analyzing electricity demand, it was necessary to convert the electricity bill information from the MICS into units of electricity consumed. We had to assign households to different tiers in order to make the calculations. This assignment was an approximation in some cases, for three major reasons. First, we lacked information on additional surcharges such as meter rent and service charges. Second, the electricity bill information was the household's average amount over the year, so that households may have consumed in different tiers in different months. Finally, some households 
may not be individually metered, and may therefore be paying a share of the bill covering two or more dwellings. Details can be found in the appendix on how households were assigned to the various tiers.

Table-4: Distribution of Households into Tariff Tiers for Lahore

\begin{tabular}{|c|c|c|}
\hline & Percentage & Electricity Tariff $^{0}$ \\
\hline Use 50 Units or Less & 3.4 & Up to 50 units at Rs. 1.675 \\
\hline Use 51 - 100 Units & 15.2 & Up to 100 units at Rs 2.613 \\
\hline Use $101-300$ Units & 65.5 & Next 200 units at Rs 3.523 \\
\hline Use $301-1,000$ Units & 15.3 & Next 700 units at Rs 5.875 \\
\hline Use More than 1,000 Units & 0.5 & Units above 1,000 at Rs 7.047 \\
\hline Total & $100 \%$ & \\
\hline
\end{tabular}

We can also take a look at the association of the tariff tier with income per capita (proxied by expenditures per capita) and appliance ownership. The clear (and expected) pattern that emerges is that of a positive relationship between income and tariff tier. In Table-5a, we can see that as we move down the expenditure deciles (signifying greater income) the likeliest tariff tier also increases. In Table-5b we see, for each tariff tier, the distribution of households across the deciles of expenditure per capita. ${ }^{11}$ In this table, a figure of greater (lesser) than $10 \%$ represents that a decile is over-represented (under-represented) in a tariff tier. As can be seen, the lower income deciles are highly represented in the low tariff tiers while the high tariff tiers are dominated by the high income deciles. The income deciles per tariff tier in which most of the consumption is concentrated lies almost at a diagonal along the table, signifying a fairly smooth relationship between income and tariff tier.

\footnotetext{
${ }^{10}$ To each of these tariffs, GST of $15 \%$ should be added.

${ }^{11}$ Similar patterns to Table-5a and $5 \mathrm{~b}$ can be seen among non-Lahore households in Appendix Table-2a and 2b.
} 
Table-5a: Distribution of Households across Tariff Tiers, by Percentile for Lahore

(By expenditure decile, distribution of $\mathrm{HH}$ into tariff tiers)

\begin{tabular}{|c|c|c|c|c|c|c|c|}
\hline & & \multicolumn{5}{|c|}{ Tariff Tier } & \multirow[b]{2}{*}{ Total } \\
\hline & & 1 & 2 & 3 & 4 & 5 & \\
\hline \multirow{10}{*}{ 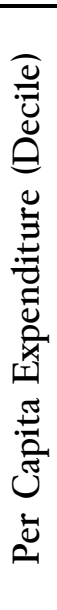 } & 1 & 9.3 & 40.5 & 48.6 & 1.6 & 0.0 & 100 \\
\hline & 2 & 6.8 & 28.6 & 59.5 & 5.1 & 0.0 & 100 \\
\hline & 3 & 2.6 & 19.6 & 67.8 & 10.0 & 0.0 & 100 \\
\hline & 4 & 4.2 & 15.5 & 68.7 & 11.6 & 0.0 & 100 \\
\hline & 5 & 4.2 & 18.1 & 57.7 & 20.0 & 0.0 & 100 \\
\hline & 6 & 1.6 & 8.7 & 70.6 & 19.0 & 0.0 & 100 \\
\hline & 7 & 1.3 & 6.8 & 64.0 & 27.9 & 0.0 & 100 \\
\hline & 8 & 1.3 & 8.3 & 59.3 & 31.1 & 0.0 & 100 \\
\hline & 9 & 2.2 & 5.4 & 51.9 & 40.1 & 0.3 & 100 \\
\hline & 10 & 0.6 & 2.2 & 26.4 & 66.9 & 3.8 & 100 \\
\hline & $\%$ of $\mathrm{HH}$ in each tier & 3.4 & 15.4 & 57.4 & 23.4 & 0.4 & 100 \\
\hline
\end{tabular}

Source: Author's calculations, based on MICS 2003/04.

Table-5b: Income Distribution of Households, by Tariff Tier for Lahore (By tariff tier, distribution of $\mathrm{HH}$ across expenditure deciles)

\begin{tabular}{|c|c|c|c|c|c|c|}
\hline & & & & iff $T$ & & \\
\hline \multirow{12}{*}{ 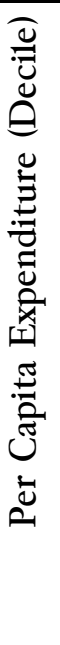 } & & 1 & 2 & 3 & 4 & 5 \\
\hline & 1 & 27.4 & 26.4 & 8.5 & 0.7 & 0.0 \\
\hline & 2 & 19.8 & 18.6 & 10.4 & 2.2 & 0.0 \\
\hline & 3 & 7.5 & 12.8 & 11.8 & 4.3 & 0.0 \\
\hline & 4 & 12.3 & 10.0 & 11.9 & 5.0 & 0.0 \\
\hline & 5 & 12.3 & 11.7 & 10.0 & 8.5 & 0.0 \\
\hline & 6 & 4.7 & 5.6 & 12.3 & 8.1 & 0.0 \\
\hline & 7 & 3.8 & 4.4 & 11.0 & 11.8 & 0.0 \\
\hline & 8 & 3.8 & 5.4 & 10.4 & 13.3 & 0.0 \\
\hline & 9 & 6.6 & 3.6 & 9.1 & 17.2 & 7.7 \\
\hline & 10 & 1.9 & 1.5 & 4.6 & 28.9 & 92.3 \\
\hline & Total & 100 & 100 & 100 & 100 & 100 \\
\hline
\end{tabular}

Source: Author's calculations, based on MICS 2003/04. 
In Table-6a, we can see how the total ownership of each appliance is distributed across tariff tiers. From this table, we can see that the majority of air conditioners, cooking ranges/microwaves and personal computers are owned by households consuming in the fourth tier. The majority of all other appliances (air coolers/fans, refrigerators/freezers, washing machines/ dryers, sewing machines, televisions, radios, and water pumps) are owned by consumers who purchase from the third tier. On the other hand, for consumers in the third tier (as well as the first and second tiers), their representation in terms of appliance ownership is less than the proportion of households in that tier. The reverse is the case for the fourth and fifth tiers. In other words, appliance ownership overall is positively related to the tariff tier in which the household consumes. This is further confirmed in Table-6b.

Table-6b shows the percentage of households in each tariff tier who own each appliance. ${ }^{12}$ As we can see, except in very few instances, the percentage of households owning a particular appliance rises as we move up the tariff structure. We can see that the share of households owning a refrigerator/freezer or a washing machine/dryer increases noticeably between the second and third tiers. In addition, the share of households owning air conditioners and cooking ranges/microwaves exhibits a large jump between the third and fourth tariff tiers. On the other hand, nearly all households have an air cooler or fan, and ownership is common across tariff tiers. Air coolers/fans, as an appliance category, are therefore unlikely to help us identify into which electricity tier a household has selected itself.

\footnotetext{
${ }^{12}$ Similar patterns to Table-6a and $6 \mathrm{~b}$ can be seen among non-Lahore households in Appendix Table-3a and $3 b$.
} 
Table-6a: Distribution Appliance Ownership across Tariff Tiers, Lahore (Percentage of appliance stock owned by each tier)

\begin{tabular}{lcccccc}
\hline & \multicolumn{7}{c}{ Tariff Tier } \\
\hline & $\mathbf{1}$ & $\mathbf{2}$ & $\mathbf{3}$ & $\mathbf{4}$ & $\mathbf{5}$ & Sum \\
\hline Air Cooler or Fan & 3.4 & 15.3 & 57.4 & 23.5 & 0.4 & 100 \\
Air Conditioner & 0.4 & 1.1 & 21.9 & 73.1 & 3.5 & 100 \\
Cooking Range or Microwave & 1.3 & 3.2 & 32.9 & 59.0 & 3.5 & 100 \\
Refrigerator or Freezer & 1.1 & 4.9 & 57.2 & 36.0 & 0.8 & 100 \\
Washing Machine or Dryer & 1.2 & 8.0 & 59.8 & 30.4 & 0.6 & 100 \\
Sewing or Knitting Machine & 2.0 & 10.8 & 59.9 & 26.7 & 0.5 & 100 \\
Television & 2.2 & 9.2 & 58.8 & 29.4 & 0.5 & 100 \\
Radio & 1.6 & 9.2 & 54.7 & 33.1 & 1.4 & 100 \\
Personal Computer & 0.4 & 2.6 & 29.9 & 64.2 & 3.0 & 100 \\
Water Pump & 2.1 & 13.2 & 59.1 & 25.4 & 0.2 & 100 \\
\% of households in each tier & 1.7 & 15.1 & 65.3 & 12.1 & 0.5 & 100 \\
\hline
\end{tabular}

Source: Author's calculations, based on MICS 2003/04.

Table-6b: Appliance Ownership by Tariff Tier, Lahore (Percentage of households in each tier who own appliance)

\begin{tabular}{|c|c|c|c|c|c|c|}
\hline & \multicolumn{5}{|c|}{ Tariff Tier } & \multirow{2}{*}{$\begin{array}{c}\text { Rate of } \\
\text { ownership } \\
\text { (\% of } \mathrm{HH})\end{array}$} \\
\hline & 1 & 2 & 3 & 4 & 5 & \\
\hline Air Cooler or Fan & 98.1 & 97.5 & 98.1 & 98.8 & 100.0 & 98.1 \\
\hline Air Conditioner & 0.9 & 0.6 & 3.4 & 28.4 & 76.9 & 9.0 \\
\hline Cooking Range or Microwave & 3.7 & 2.1 & 5.7 & 25.1 & 84.6 & 9.9 \\
\hline Refrigerator or Freezer & 17.8 & 17.2 & 54.0 & 83.8 & 100.0 & 54.3 \\
\hline Washing Machine or dryer & 23.4 & 35.1 & 70.4 & 88.4 & 100.0 & 67.7 \\
\hline Sewing or Knitting Machine & 42.1 & 49.6 & 73.5 & 80.8 & 84.6 & 70.5 \\
\hline Television & 43.9 & 41.1 & 70.5 & 87.0 & 84.6 & 11.8 \\
\hline Radio & 5.6 & 7.1 & 11.2 & 16.7 & 38.5 & 69 \\
\hline Personal Computer & 0.9 & 1.5 & 4.4 & 23.6 & 61.5 & 8.6 \\
\hline Water Pump & 15.9 & 22.2 & 26.7 & 28.2 & 15.4 & 25.9 \\
\hline$\%$ of households in each tier & 1.7 & 15.1 & 65.3 & 12.1 & 0.5 & \\
\hline
\end{tabular}

Source: Author's calculations, based on MICS 2003/04. 


\section{Estimation Strategy}

Despite the rich literature on kinked budget constraints, the analysis based on the MICS presented difficulties. The more sophisticated procedures, including GMM and maximum likelihood (including discretecontinuous choice models), rely on significant variation in the pricing and weather data in order to identify the parameters of interest, particularly price elasticity and appliance utilization (respectively). Given that both the weather and price information were uniform across households for all observations, these estimation strategies could not be implemented and the price elasticity of demand could not be calculated. ${ }^{13}$ Also compounding the difficulty of the analysis was that only average annual electricity consumption could be approximated.

Instead, we consider a model of electricity demand along the lines of an endogenous switching model (to account for the tariff tier chosen by the household) for inclusion in the estimation of the demand equation. ${ }^{14} \mathrm{We}$ incorporate heterogeneity in appliance ownership categories and residence size in order to identify the tiers chosen by households. We then estimate electricity demand for sub-samples of two tiers each, for tiers 2 and 3 , and then on tiers 3 and $4 .{ }^{15}$ Since we are considering only a cross-section of households, this analysis should be considered a short-run model, and therefore the endogeneity of marginal electricity price and appliance stock need not be taken into account.

\footnotetext{
13 As pointed out in Moffitt (1990), regressions of electricity usage on price in an increasing block regime lead to positive slope estimates for price; essentially such a regression maps out the budget constraint.

${ }^{14}$ Endogenous switching models, estimated with Stats's "movestay" command, use maximum likelihood methods to estimate two separate regression models (in this case, electricity demand for two different tiers) when there is endogenous switching between regimes (here, tariff tiers) and only one regime is observed. It is more comprehensive than the basic Heckit models, which combine a single regression model with a selection equation, but less sophisticated than the discrete-continuous choice framework that is able to incorporate all consumers in a single estimation and also models the decision to locate at a "kink".

15 The regressions could not estimated for tiers $1 / 2$ and $4 / 5$ because the number of households in tiers 1 and 5 were too small.
} 
Table-7: Ordered Probit of Tariff Tiers $1-4^{16}$

Number of observations: 3055

Pseudo $\mathrm{R}^{2}=0.27$

\begin{tabular}{lcc}
\hline & Coefficient & z-statistic \\
\hline No. Children Under 5 & 0.010 & 0.390 \\
No. Rooms & -0.004 & -1.730 \\
No. Household Members & 0.016 & 1.610 \\
Air Conditioner & $0.294^{* *}$ & 2.810 \\
Refrigerator/Freezer & $0.316^{* *}$ & 5.260 \\
Washing Machine/Dryer & $0.179^{* *}$ & 2.870 \\
Sewing Machine & -0.040 & -0.750 \\
Television & 0.049 & 0.880 \\
Water Pump & $0.215^{* *}$ & 4.040 \\
Urban Dummy & -0.015 & -0.240 \\
Ln(Virtual Expend) & $1.417^{* *}$ & 24.080 \\
Pacca Construction Dummy & 0.087 & 1.350 \\
\hline
\end{tabular}

***, and + refer to statistical significance at the 1,5 , and $10 \%$ levels respectively.

In estimating electricity demand, not just the household's money income but the "virtual income" derived from the increasing block nature of electricity tariffs must be considered. Details of the calculations of virtual income for households in Lahore are given in Annex $2 .{ }^{17}$ As it turns out, for the sample under consideration, virtual income does not have a dramatic impact; for $90 \%$ of households, the adjustment accounts for $5 \%$ or less of total household expenditures.

As a first step, we look at the result of an ordered probit model of the tariff tier on income and appliance data and basic household characteristics (such as number of household members and number of rooms in dwelling) in order to get a sense of which appliances lead to a jump between tariff tiers (Table-7). We can see that the tariff tier households consume in are positively and significantly related to income and ownership of air conditioners, refrigerators/freezers, washing machines, and water

\footnotetext{
${ }^{16}$ There were too few tariff 5 customers to include them in the regressions.

${ }^{17}$ Virtual expenditure is used as a proxy for virtual income.
} 
pumps. These are appliances that are considered energy intensive and/or are likely to be in use for relatively more hours per day (See Appendix Table-4).

The results of the electricity demand model (with endogenous switching) are presented in Tables- 8 and 9 below. In the demand regression on the sub-sample of tariff tiers 2 and 3 (Table-8), household virtual expenditures, ownership of a water pump, and urban location dummy are statistically significant in the demand equations for both tier 2 and tier 3 households. Most of the same variables are significant in the selection equation, except the urban dummy. Despite its lack of significance in the demand equation, ownership of an air conditioner is positively related to a household selecting up into the third tariff tier. 
Table-8: Endogenous switching model, Dependent variable: ln(electricity demand)

Sub-sample of Tier 2 and 3 households

Number of observations: 2272

\begin{tabular}{lcc}
\hline & Coefficient & z-statistic \\
\hline lnDDelec Tier 3 & & \\
\hline No. Children Under 5 & 0.007 & 1.190 \\
No. Household Members & 0.002 & 0.850 \\
Ln(Virtual Expend) & $0.194^{* *}$ & 12.020 \\
Air Conditioner & 0.041 & 1.260 \\
Cooking Range/Microwave & -0.011 & -0.440 \\
Refrigerator/Freezer & $0.038^{* *}$ & 2.720 \\
Washing Machine/Dryer & 0.010 & 0.700 \\
Sewing Machine & 0.001 & 0.090 \\
Television & 0.003 & 0.200 \\
Water Pump & $0.046^{* *}$ & 3.530 \\
\hline Urban Dummy & $0.034^{*}$ & 2.260 \\
\hline lnDDelec Tier 2 & & 0.970 \\
\hline No. Household Members & 0.004 & 12.760 \\
Ln(Virtual Expend) & $0.352^{* *}$ & 4.020 \\
Cooking Range/Microwave & $0.096^{* *}$ & 0.760 \\
Refrigerator/Freezer & 0.017 & 1.460 \\
Washing Machine/Dryer & 0.029 & 1.550 \\
Television & 0.031 & 3.040 \\
Water Pump & $0.065^{* *}$ & 1.800 \\
\hline Urban Dummy & $0.038+$ & \\
\hline Selection Equation & & 0.200 \\
\hline No. Children Under 5 & 0.002 & 0.630 \\
No. Household Members & 0.009 & 13.980 \\
Ln(Virtual Expend) & $1.308^{* *}$ & 5.950 \\
Air Conditioner & $0.643^{* *}$ & 1.800 \\
Cooking Range/Microwave & -0.040 & 1.020 \\
Refrigerator/Freezer & $0.345^{* *}$ & 1.440 \\
Washing Machine/Dryer & 0.119 & 2.460 \\
Television & 0.071 & -0.120 \\
Water Pump & 0.103 & \\
Urban Dummy & $0.185^{*}$ & \\
No. Rooms & 0.00007 & \\
\hline & & \\
\hline
\end{tabular}

$*^{* *}$, , and + refer to statistical significance at the 1,5 , and $10 \%$ levels respectively. 
The results for demand regression on the sub-sample of tariff tiers 3 and 4 are less clear (Table-9), primarily for tier 4 households. Electricity use by tier 3 households is positively and significantly related to the number of household members, household virtual expenditure, and ownership of refrigerator/freezers, washing machine/dryers, and water pumps. The elasticity of electricity demand to income (measured as virtual expenditure) is 0.21 in this specification, which is very similar to the estimate of 0.19 in the tier $2 / 3$ specification. Among tier 4 households, electricity consumption is positively and significantly related to household virtual expenditure, but negatively (and sometimes with statistically significance) related to household appliance ownership. These odd results are possibly due to significant unobserved consumer heterogeneity in appliance utilization among households consuming in the fourth tier. On the other hand, the variable aggregating ownership of appliances likely to be in constant usage ("Sum Appl Constant Use" in the table) has a positive and significant coefficient in the selection equation for the fourth tier. ${ }^{18}$ The income elasticity of electricity demand for tier 4 households was estimated to be 0.16 .

In addition, we looked at specifications of demand for tiers 2, 3, and 4 individually. The results for the second tier were weak (in terms of explanatory power) but one interesting and statistically significant parameter was the estimated the income elasticity of demand, which was quite low at $0.08 .{ }^{19}$ This is much lower than the estimate of 0.35 from the endogenous switching model results in Table-8, and demonstrates the importance of correcting for the endogenous selection into tariff tiers. The income elasticities of electricity demand (in the tier by tier regressions) are estimated to be 0.31 and 0.15 for third and fourth tier households respectively (Appendix Table-5a and 5b). For the fourth tier, the estimate is nearly the same as for the endogenous switching model (Table-9), but for tier 3 households, the estimate of income elasticity is substantially higher when the third tier is considered separately. Similar to the endogenous switching regressions, the tier by tier regression was better specified (in terms of statistical significance and expected coefficient signs) for the third tier as compared to the households consuming in the second and fourth tiers.

\footnotetext{
${ }^{18}$ This variable refers to appliances that are most likely to be in continuous use (fan/air cooler, air conditioner, refrigerator/freezer, and television).

${ }^{19}$ These results have not been reported in the paper but are available upon request.
} 
Table-9: Endogenous switching model, Dependent variable: ln(electricity demand)

Sub-sample of Tier 3 and 4 Households

Number of observations $=2523$

\begin{tabular}{lcc}
\hline & Coefficient & z-statistic \\
\hline lnDDelec Tier 4 & & \\
\hline No. Children Under 5 & 0.007 & 0.580 \\
No. Household Members & -0.004 & -0.920 \\
Ln(Virtual Expend) & $0.155+$ & 1.930 \\
Cooking Range/Microwave & 0.031 & 0.930 \\
Refrigerator/Freezer & $-0.063+$ & -1.770 \\
Washing Machine/Dryer & $-0.059+$ & -1.720 \\
Sewing Machine & -0.017 & -0.650 \\
Television & 0.007 & 0.190 \\
Water Pump & $-0.044+$ & -1.660 \\
Urban Dummy & 0.016 & 0.570 \\
\hline lnDDelec Tier 3 & & \\
\hline No. Household Members & $0.005+$ & 1.880 \\
Ln(Virtual Expen) & $0.210^{* *}$ & 11.020 \\
Refrigerator/Freezer & $0.058^{* *}$ & 3.710 \\
Washing Machine/Dryer & $0.026+$ & 1.650 \\
Sewing Machine & 0.003 & 0.220 \\
Television & 0.018 & 1.260 \\
Water Pump & $0.054^{* *}$ & 3.620 \\
Urban Dummy & $0.031^{*}$ & 2.110 \\
\hline Selection Equation & & \\
\hline No. Children Under 5 & $0.068+$ & 1.780 \\
No. Household Members & 0.012 & 0.720 \\
Ln(Virtual Expend) & $1.284^{* *}$ & 11.310 \\
Cooking Range/Microwave & -0.145 & -0.990 \\
Refrigerator/Freezer & $-0.580+$ & -1.730 \\
Washing Machine/Dryer & -0.018 & -0.150 \\
Sewing Machine & -0.135 & -1.460 \\
Television & $-0.821^{*}$ & -2.460 \\
Water Pump & 0.092 & 1.120 \\
Urban Dummy & -0.077 & -0.780 \\
No. Rooms & -0.001 & -0.490 \\
Air Conditioner & -0.334 & -0.990 \\
Sum App1 Constant Use & $0.853^{* *}$ & 2.650 \\
\hline & & \\
& & \\
\hline
\end{tabular}

$* * *$, and + refer to statistical significance at the 1,5 , and $10 \%$ levels respectively. 


\section{Conclusions}

Electricity demand depends positively on both income and appliance ownership. As we can see from Tables-1 and 2, appliance ownership has increased dramatically and nearly all households have electricity connections. While positive from a development and utility maximization standpoint, such increases will only exacerbate the energy crisis currently facing Pakistan.

One policy proposal (in California, during the crisis of 2000/01) has been to increase the number of tiers for the electricity tariffs from two to up to five different tiers. The goal of such policies is to increase revenues for utilities while protecting poorer households. Punjab already has five tiers in its electricity tariff schedule. But given the fact that around $80 \%$ of households consume in only two tiers, with two thirds of households in the third tier alone and income elasticity low (estimates ranging from about 0.15 to 0.3 ), there is room for adjustment in the tariff schedule by perhaps reducing the maximum units in the third tier from its current level of 300. This would shift some households from the third tier into the fourth tier, leading to increases in revenues and reduction in demand. In Lahore, among the consumers clustered at the upper end of the third tier, $70 \%$ are in the 6th income percentile or higher. Even in the fourth tier, those households consuming above 450 units are in the 7 th-10th income deciles, and with the vast majority in the 9 th and 10 th deciles, so that the maximum units for the fourth tier, currently 1,000 , might also be reduced. ${ }^{20}$ In addition, those already consuming in the highest tiers should also have to shoulder some of the burden through higher tariffs. As we can see in Table-5b, in Lahore (at least) all of the households consuming in the highest tariff tier are in the 9th and 10th income deciles (as measured by expenditures per capita). Therefore, some additional increases in the highest tariff tier could also be considered.

${ }^{20}$ A note of caution: these conclusions have been made based on households in Lahore, which tend to be relatively wealthier. 


\section{References}

Borenstein, S. (2009). To What Electricity Price Do Consumers Respond? Residential Demand Elasticity Under Increasing-Block Pricing. Working Paper, Mimeo.

Burney, N., and Akhtar, N. (1990). Fuel Demand Elasticities in Pakistan: An Analysis of Households' Expenditure on Fuels using Micro Data. The Pakistan Development Review, 29(2), 155 - 174.

Chaudhry, T., and Chaudhry, A. (2008). The Effect of Rising Food and Fuel Costs on Poverty in Pakistan. The Lahore Journal of Economics, Special Edition, 117-138.

Filippini, M., and Pachauri, S. (2002). Elasticities of Electricity Demand in Urban Indian Households. CEPE Working Paper \#16, Centre for Energy Policy and Economics, Swiss Federal Institutes of Technology, Zurich.

Hanemann, W.M. (1984). Discrete/Continuous Models of Consumer Demand. Econometrica, 52(3), 541-561.

Hausman, Jerry (1979). The Econometrics of Labor Supply on Convex Budget Sets. Economic Letters, 3(2), 171-174.

Hausman, J. (1985). The Econometrics of Non-Linear Budget Sets. Econometrica, 53 (6), 1255-82.

Heckman, J. (1979). Sample Selection Bias as a Specification Error. Econometrica, 47, 153-161.

Ito, K. (2010). How Do Consumers Respond to Nonlinear Pricing? Evidence from Household Electricity Demand. Working paper, Mimeo.

Iyengar, R. (2006). A Structural Demand Analysis for Wireless Services Under Nonlinear Pricing Schemes. Working Paper, The Wharton School, University of Pennsylvania.

Khan, A., and Ahmed, U. (2009). Energy Demand in Pakistan: A Disaggregate Analysis. Paper presented at the $24^{\text {th }}$ Annual General Meeting and Conference of the Pakistan Society of Development Economists, March 31-April 2, 2009, Islamabad. 
Maddock, R., Castano, E., and Vella, F. (1992). Estimating Electricity Demand: The Cost of Linearising the Budget Constraint. The Review of Economics and Statistics, 74(2), 350-354.

McRae, S. (2009). Infrastructure Quality and the Subsidy Trap. Stanford Institute for Economic Policy Research Discussion Paper 09-017.

Madlener, R. (1996). Econometric Analysis of Residential Energy Demand: A Survey. The Journal of Energy Literature, 2(2), 3-32.

Moffit, R. (1990). The Econometrics of Kinked Budget Constraints. The Journal of Economic Perspectives, 4(2), 119-139.

Olmstead, S. (2009). Reduced-Form versus Structural Models of Water Demand under Nonlinear Prices. Journal of Economic and Business Statistics, 87(1), 84-94.

Ransom, M. (1987). An Empirical Model of Discrete and Continuous Choice in Family Labor Supply. The Review of Economics and Statistics, 69(3), 465-472.

Reiss, P., and White, M. (2005). Household Electricity Demand, Revisited. Review of Economic Studies, 72(3), 853-883.

Siddiqui, R. (2004). Energy and Economic Growth in Pakistan. The Pakistan Development Review, 43(2), 175-200.

Siddiqui, R. (1999). Demand for Energy and the Revenue Impact of Changes in Energy Prices. Research Report \#174, Pakistan Institute for Development Economics, Islamabad.

Tariq, M., Nasir, M., and Arif, A. (2009). Residential Demand for Electricity in Pakistan. Paper presented at the $24^{\text {th }}$ Annual General Meeting and Conference of the Pakistan Society of Development Economists, March 31-April 2, 2009, Islamabad. 


\section{Annex 1: Electricity Rates and Computation of Electricity Usage}

Rates from a sample Lahore Bill July 2003, with 15\% GST added to compute Minimum and Maximum Bills

\begin{tabular}{lccc}
\hline & & Min Bill & Max Bill \\
\hline Less Than 50 units & na & na & na \\
For more than 50, 1- 100 Units & 2.613 & 153.2525 & 300.495 \\
101-300 Units & 3.523 & 304.5515 & 1110.79 \\
301-1000 Units & 5.875 & 1117.756 & 5840.375 \\
$>1000$ Units & 7.047 & 5848.504 & no max \\
\hline
\end{tabular}

Published Electricity Tariffs for May 2003 (Source: Economic Survey 200607), with $15 \%$ GST added to compute Minimum and Maximum Bills

\begin{tabular}{lccccccc}
\hline & $\begin{array}{l}\text { Energy } \\
\text { Charge }\end{array}$ & FAS & Surcharge Subsidy & Total Min Bill & Max Bill \\
\hline $\begin{array}{l}\text { Less Than } \\
50 \text { units }\end{array}$ & 0.61 & - & 0.73 & & 1.34 & 1.54 & 77.05 \\
\hline $\begin{array}{l}\text { For more } \\
\text { than 50, } \\
\begin{array}{l}1-100 \\
\text { Units }\end{array}\end{array}$ & 0.41 & 0.5 & 1.58 & 0.44 & 2.05 & 120.2325 & 235.75 \\
\hline $\begin{array}{l}101-300 \\
\text { Units }\end{array}$ & 0.58 & 0.5 & 2.29 & 0.44 & 2.93 & 239.1195 & 909.65 \\
\hline $\begin{array}{l}301-1000 \\
\text { Units }\end{array}$ & 1.51 & 0.5 & 3.55 & 0.44 & 5.12 & 915.538 & 5031.25 \\
\hline $\begin{array}{l}\text { 1000 } \\
\text { Units }\end{array}$ & 1.88 & 0.38 & 4.42 & 0.32 & 6.36 & 5038.564 & no max \\
\hline
\end{tabular}




\section{Computations of Electricity Usage}

For Less that 50 units, tariffs from Economic Survey 2006, effective May 10, $2003+25 \%$ to adjust for Lahore's generally higher rates:

Rs. 1.675 per unit $+15 \%$ GST (Max bill Rs. 96.3)

For more than 50 units, tariffs from July 2003 Sample Electricity Bill (Lahore):

100 units at $2.613+15 \%$ GST (Min bill 151, Max bill Rs. 300.5)

Next 200 units at $3.523+15 \%$ GST (Max bill Rs. 1111)

Next 700 units at $5.875+15 \%$ GST (Max bill Rs. 5840)

Units above 1000 at $7.047+15 \%$ GST 


\section{Annex 2: Calculation of Virtual Expenditure and Income}

The Household's Virtual Income*, under Nonlinear Budget Constraint with Increasing Block Tariffs

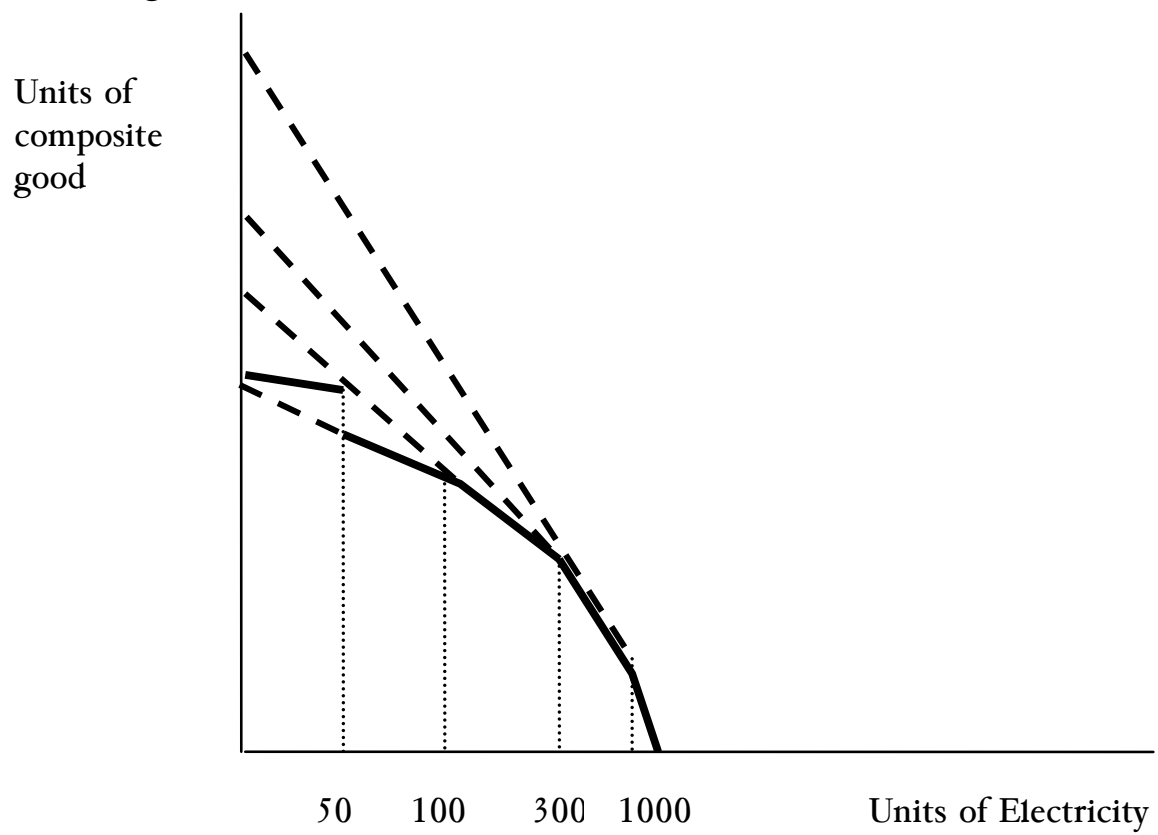

* In the figure above, virtual income is indicated by the dotted budget constraint

VExpend =Expend+DBil1301 to1110*105+DBil11111 to5840*918+DBillMore5840*2258

\begin{tabular}{cc}
\hline Tier & $\begin{array}{c}\text { Adjustment (Added to HH Total Expenditure or Income } \\
\text { to Get Virtual Expenditure/Income) }\end{array}$ \\
\hline 1 & No Adjustment \\
2 & No Adjustment \\
3 & Rs105=(100)(4.05-3) \\
4 & Rs918 $=105+(300)(6.76-4.05)$ \\
5 & Rs2258 $=918+1000(8.10-6.76)$ \\
\hline
\end{tabular}




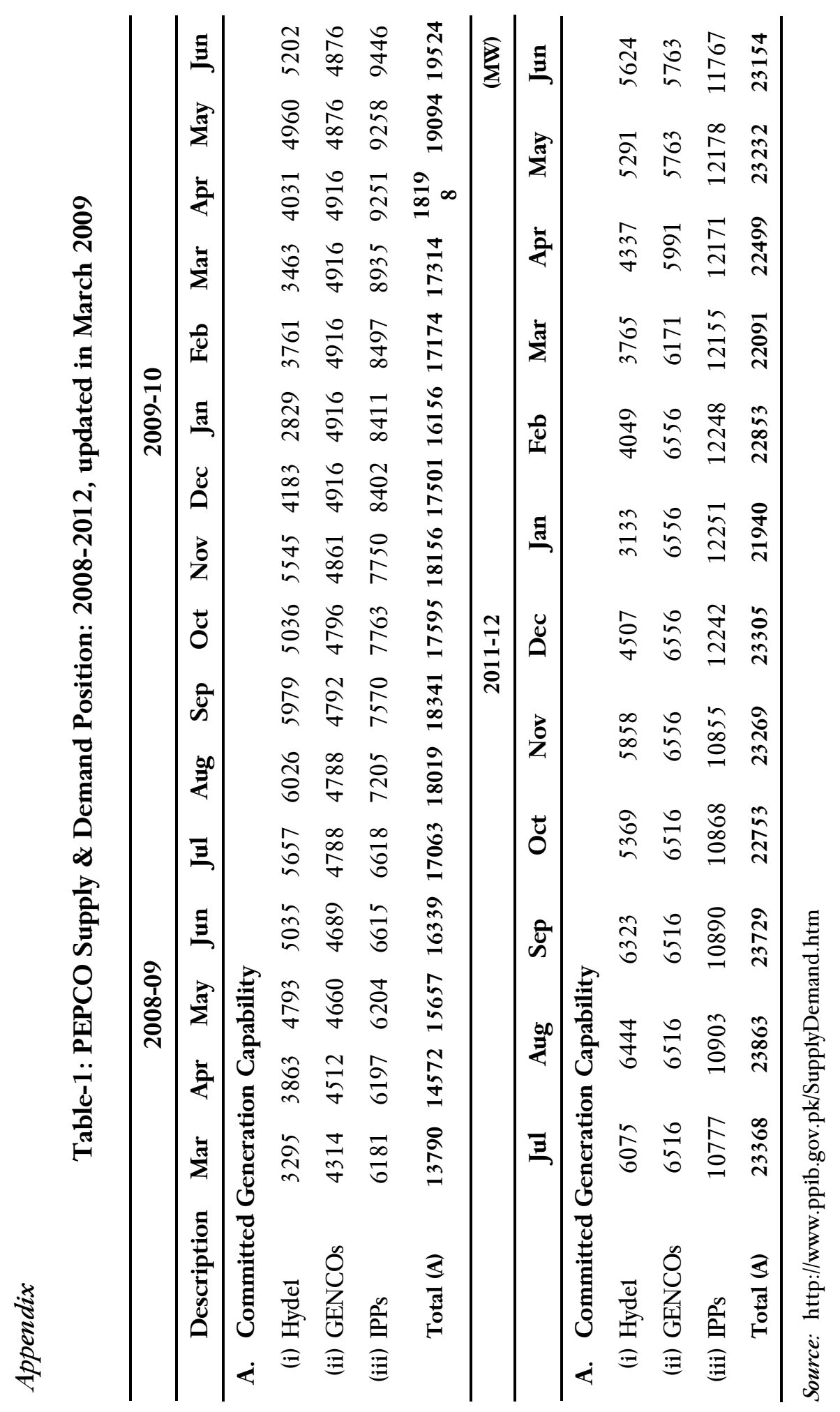


Appendix

Table-2a and 2b: Cross-Tabulations of Total Household Expenditure Per Capita Against Electricity Tariff Tier

Table-2a: Distribution of Households across Tariff Tiers, by Expenditure Per Capita for non-Lahore Households (By expenditure decile, distribution of $\mathrm{HH}$ into tariff tiers)

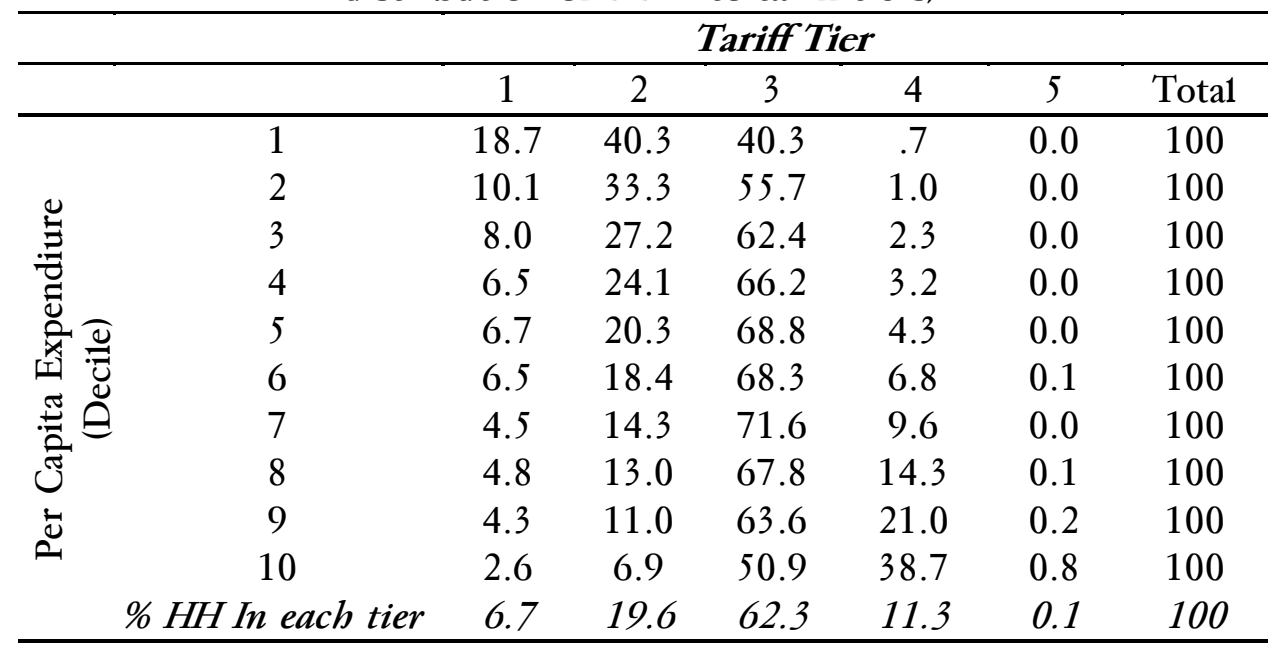

(Source: Author's calculations, based on MICS 2003-04)

Table-2b: Distribution of Households across Tariff Tiers, by Expenditure Per Capita for non-Lahore Households (By tariff tier, distribution of $\mathbf{H H}$ across expenditure deciles)

\begin{tabular}{|c|c|c|c|c|c|c|c|}
\hline & \multicolumn{7}{|c|}{ Tariff Tier } \\
\hline & & 1 & 2 & 3 & 4 & 5 & Total \\
\hline \multirow{11}{*}{ 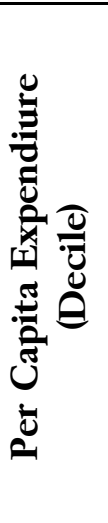 } & 1 & 19.3 & 14.3 & 4.5 & .4 & 0.0 & 6.9 \\
\hline & 2 & 12.8 & 14.5 & 7.6 & .7 & 0.0 & 8.5 \\
\hline & 3 & 11.2 & 13.1 & 9.4 & 1.9 & 3.2 & 9.4 \\
\hline & 4 & 9.6 & 12.2 & 10.5 & 2.9 & 0.0 & 9.9 \\
\hline & 5 & 10.3 & 10.6 & 11.3 & 3.9 & 0.0 & 10.3 \\
\hline & 6 & 10.0 & 9.7 & 11.3 & 6.3 & 6.5 & 10.4 \\
\hline & 7 & 7.3 & 7.9 & 12.5 & 9.2 & 3.2 & 10.8 \\
\hline & 8 & 7.9 & 7.3 & 12.0 & 13.9 & 6.5 & 11.0 \\
\hline & 9 & 7.1 & 6.3 & 11.4 & 20.9 & 12.9 & 11.2 \\
\hline & 10 & 4.5 & 4.1 & 9.5 & 39.9 & 67.7 & 11.6 \\
\hline & Total & 100 & 100 & 100 & 100 & 100 & 100 \\
\hline
\end{tabular}

(Source: Author's calculations, based on MICS 2003-04) 
Table-3a and 3b: Cross-Tabulations of Appliance Ownership Against Electricity Tariff Tier

Table-3a: Distribution of Appliance Ownership across Tariff Tiers, nonLahore Households (Percentage of appliance stock owned by households in each tariff tier)

\begin{tabular}{lcccccc}
\hline & \multicolumn{7}{c}{ Tariff Tier } \\
\hline & 1 & 2 & 3 & 4 & 5 & Sum \\
\hline Air cooler or Fan & 6.4 & 19.2 & 62.7 & 11.5 & 0.1 & 100 \\
Air conditioner & 0.7 & 1.1 & 27.8 & 67.3 & 3.1 & 100 \\
Cooking Range or & & & & & & \\
Microwave & 0.5 & 0.7 & 33.9 & 62.2 & 2.8 & 100 \\
Refrigerator or Freezer & 1.1 & 4.5 & 64.1 & 29.9 & 0.4 & 100 \\
Washing machine or dryer & 1.6 & 7.8 & 67.6 & 22.7 & 0.3 & 100 \\
Sewing or Knitting Machine & 3.6 & 13.7 & 66.7 & 15.9 & 0.2 & 100 \\
Radio & 4.4 & 15.6 & 63.4 & 16.4 & 0.2 & 100 \\
Television & 2.3 & 10.3 & 67.4 & 19.8 & 0.3 & 100 \\
Personal Computer & 1.3 & 1.6 & 36.7 & 58.4 & 2.0 & 100 \\
Water pump & 2.2 & 10.6 & 68.2 & 18.7 & 0.3 & 100 \\
$\quad$ \% HH In each tier & 6.7 & 19.6 & 62.3 & 11.3 & 0.1 & 100 \\
\hline
\end{tabular}

(Source: Author's calculations, based on MICS 2003-04) 
Table-3a: Distribution of Appliance Ownership by Tariff Tiers for nonLahore Households (Percentage of households in each tier who own appliance)

\begin{tabular}{lrrrrrcc}
\hline & \multicolumn{4}{c}{ Tariff Tier } & & Total \\
\cline { 2 - 7 } & \multicolumn{1}{c}{$\mathbf{1}$} & \multicolumn{1}{c}{$\mathbf{2}$} & \multicolumn{1}{c}{3} & $\mathbf{4}$ & $\mathbf{5}$ & $\begin{array}{c}\text { Rate of } \\
\text { ownership } \\
\text { (\% of HH) }\end{array}$ \\
\hline Air Cooler/Fan & 92.4 & 95.1 & 97.3 & 98.5 & 100.0 & 96.7 \\
Air conditioner & 0.3 & 0.1 & 1.1 & 14.6 & 54.8 & 2.4 \\
Washing machine or dryer & 9.8 & 16.4 & 44.4 & 82.4 & 77.4 & 40.9 \\
Sewing or Knitting Machine & 30.6 & 40.2 & 61.6 & 81.1 & 80.6 & 57.6 \\
Radio & 9.4 & 11.5 & 14.7 & 21.0 & 25.8 & 14.4 \\
Television & 15.6 & 24.0 & 49.3 & 80.1 & 83.9 & 45.6 \\
Personal Computer & 0.5 & 0.2 & 1.4 & 12.5 & 35.5 & 2.4 \\
Water pump & 12.6 & 21.0 & 42.5 & 64.6 & 87.1 & 38.8 \\
\hline
\end{tabular}

(Source: Author's calculations, based on MICS 2003-04) 
Table-4: Energy Intensity of Various Appliances

\begin{tabular}{lc}
\hline Appliance & Load (Watts) \\
\hline Air Conditioner & $900-3500$ \\
Air Cooler & $200-325$ \\
Ceiling Fan & $60-100$ \\
Computer & $45-520$ \\
Freezer & $1080-1240$ \\
Microwave & 1400 \\
Refrigerator & $200-800$ \\
Television & $200-300$ \\
Washing Machine & 700 \\
Water Pump & $370-1110$ \\
\hline
\end{tabular}

Sources: www.pepco.gov.pk and http://samnun.com/LoadChart.htm1

We consider the high energy intensive appliances to be air conditioners, cooking range/microwaves, washing machine/dryers, and water pumps.

The appliances most likely to be in constant use are air coolers/fans and air conditioners (in the summer months) and refrigerator/freezers and televisions (year round). 
Table-5a and 5b: Regressions for Electricity Demand by Tariff Tier

Table-5a: Tobit Determinants of Tariff Tier 3

Number of Observations: 2242

Pseudo R2 $=0.41$

$\begin{array}{lcc} & \text { Coef. } & \text { t-stat } \\ \text { No. Children Under 5 } & 0.001 & 0.100 \\ \text { No. Rooms } & -0.001^{*} & -2.240 \\ \text { No. Household Members } & 0.009^{* *} & 3.210 \\ \text { Refrigerator/Freezer } & 0.092^{* *} & 5.920 \\ \text { Washing Machine/Dryer } & 0.062^{* *} & 3.630 \\ \text { Sewing Machine } & -0.008 & -0.510 \\ \text { Television } & 0.032^{*} & 2.070 \\ \text { Water Pump } & 0.072^{* *} & 4.830 \\ \text { Urban Dummy } & 0.037+ & 1.890 \\ \text { Ln(Virtual Expend) } & 0.312^{* *} & 20.430 \\ \text { Pacca Construction Dummy } & 0.024 & 1.310\end{array}$

Notes: Standard errors have been adjusted for sampling weights given in the MICS data set. **,*, and + refer to statistical significance at the 1,5 , and $10 \%$ levels respectively. 
Table-5b: OLS Determinants of Tariff Tier 4

Number of Observations: 479

Adjusted R2 $=0.27$

\begin{tabular}{lccc}
\hline & Coef. & t & P>t \\
\hline No. Rooms & 0.0003 & 0.420 & 0.678 \\
No. Children Under 5 & 0.011 & 1.120 & 0.261 \\
No. Household Members & 0.003 & 0.350 & 0.725 \\
Air Conditioner & 0.042 & 1.620 & 0.106 \\
Cooking Range/Microwave & -0.023 & -0.930 & 0.353 \\
Refrigerator/Freezer & -0.024 & -0.660 & 0.512 \\
Washing Machine/Dryer & -0.024 & -0.560 & 0.576 \\
Sewing Machine & -0.019 & -0.650 & 0.513 \\
Television & -0.017 & -0.480 & 0.628 \\
Water Pump & $-0.042^{*}$ & -2.060 & 0.040 \\
Ln(Virtual Expend) & $0.151^{*}$ & 2.370 & 0.018 \\
Ln(Expend per capita) & 0.074 & 1.280 & 0.202 \\
\hline
\end{tabular}

Notes: Few observations were censored, therefore Tobit was unnecessary. Standard errors have been adjusted for sampling weights given in the MICS data set.

$* * *$, and + refer to statistical significance at the 1,5 , and $10 \%$ levels respectively. 